\title{
Diversity of Rattan Species in Production Forest in Central Sulawesi, Indonesia
}

\author{
Musdalifah Nurdin, A Tanra Tellu*, Syech Zaenal \\ Biology Education, Faculty of Teacher Training and Education, Tadulako University, Palu 94118, Indonesia
}

Corresponding Author Email: tanratellu@untad.ac.id

https://doi.org/10.18280/ijdne.160211

Received: 25 February 2021

Accepted: 10 April 2021

\section{Keywords:}

rattan, diversity, production forest

\begin{abstract}
This study aims to explain the diversity of rattan species from production forests in Central Sulawesi. Data collection was carried out with a strip random sampling scheme, in which the sampled strips were $20 \times 100 \mathrm{~m}$. Our observation revealed that in the production forest area in Parigi Moutong and Sigi Regencies about 17 species of rattan were identified, which were divided into two genera, each with 14 species of Calamus and 3 species of Daemonorops. The distribution of eleven species was uniform, the distribution of four species was not uniform, and three species had a clumped distribution. The importance of each species varies. There are 8 species with a relatively high mean importance value: Calamus zollingerii (36.62), Calamus ornatus var. celebicus Becc. (24.62), Calamus oodersianus Becc. (23.56), Calamus ornatus var. celebicus Becc. (lambang) (23.49), Calamus didymocarpus (Mart) Becc. (22.99), Calamus inops Becc. (22.25), Calamus sp. (sambuta) (18.00), and Calamus lejocaulis Becc. (15.82), while $C$. minahassae (dato) has the lowest importance value (6.05). It disclosed, the number of species and distribution of rattan in the production forest of the Central Sulawesi are relatively high and varies.
\end{abstract}

\section{INTRODUCTION}

Rattan (Figure 1), including the Palmae family, is classified as subordinate taxa of the Lepidocaryoideae tribe [1,2]. Rattan flourishes in tropical regions, including Indonesia. In Indonesia, rattan grows naturally and is widespread in Java, Sumatra, Kalimantan, Sulawesi, and Irian Jaya [3, 4]. Rattan grows especially well in Sulawesi, particularly in the areas of Kendari, Kolaka, Towuti, Donggala, Poso, Boul Toli-toli, Gorontalo, Palopo, Buton, and the Latimojong Mountains [5, 6]. Rattan is one of the forest products that can be developed as a commodity both for domestic needs and as an export material [7]. The use of rattan products at home and abroad, both as furniture and household accessories in craft form [8, 9]. Central Sulawesi has extensive natural forests and is covered with various types of rattan. These data are necessary for planning the development and cultivation of rattan in an integrated manner. Data about the potential species, productivity, and distribution patterns of rattan have not been much collected, except in conservation forests [10].

Based on the development of the global demand for highquality rattan types, the business of logging rattan species has increased as well $[11,12]$. The need for world rattan from Indonesia reaches $190,000-220,000$ tons per year [5, 13]. The consequence is a decreasing population size of rattan types because rattan harvesting is not balanced with cultivation efforts. Also, there have been no attempts to look for alternative rattan types outside of those types that have been traded historically. As a result, the supply of rattan has diminished. Another factor causing the decline in the rattan population is its slow growth process. Therefore, to meet the increasing demand for high-quality rattan, business actors need to look for unexploited high-quality rattan as an alternative raw material for rattan products [14]. However, the quality and quality levels of the untouched rattan are not known.

Knowledge about rattan morphology characteristics is quite complete, but other features are still very limited, such as anatomical, physical, mechanical, chemical, physiological, and ecological characteristics [15]. This is due to a lack of research on rattan. For this reason, further research toward rattan, particularly on those characteristics, is needed to better understand more types of rattan in order to get to know rattan better [16].

Rattan inventories performed systematically, detailed, and comprehensively have not been carried out until now. Thus, the data and information needed regarding the potential types, patterns of distribution, and the possibility of cultivating rattan species in Central Sulawesi are still incomplete. Central Sulawesi is one of the largest producers of rattan in Indonesia because it has high species potential and productivity $[17,18]$. Specific research on the potential species and the pattern of productivity within the distribution of rattan species in Central Sulawesi has been carried out in several conservation forest areas (i.e., protected forests), such as Lore Lindu National Park, Morowali Nature Reserve, Tinombala Protected Forest, etc. [19]. However, especially in production forests, such research has never been conducted. Therefore, this research was carried out to complement accurate information about the potential species, the rattan patterns of distribution, the rattan productivity level, and the possibility of rattan cultivation, especially in the Siniu and Namo production forests. The two areas were chosen considering that the two locations were areas that had been officially designated as production forests by the Central Sulawesi Provincial Forestry Service in the form of a Forest Management Group (FMG) that made rattan 
as one of the production areas.

Based on the above, to support the germplasm inventory and identify the potential rattan species, the productivity, the distribution patterns, and the possibility for cultivation need to be examined immediately. In this study, the survey was limited specifically to the diversity, potential types, and patterns of distribution of rattan species that grow in production forests and their use as teaching material for high plant botany classes.

Research on the diversity, potential species, productivity, and patterns of distribution of rattan species in the Siniu production forest, Parigi Moutong Regency and Namo, Kulawi sub-district has never been done. Such data are necessary to compile the world biodiversity baseline and foster and preserve the germplasms for rattan types in Indonesia, especially in Central Sulawesi.

This study aimed to reveal the state of rattan growing in the Parigi Moutong and Sigi, Central Sulawesi production forest, and its development as teaching material for the High Botanical Botany class. It is intended to 1) identify the types of rattan that grow naturally in the production forests of Central Sulawesi, 2) describe the characteristics of the types of rattan that grow naturally in the production forests of Parigi Moutong and Sigi, Central Sulawesi, and 3) explain the pattern of the distribution of rattan species that grow naturally in the Parigi Moutong and Sigi, Central Sulawesi Production Forests.

\section{MATERIALS AND METHODS}

The main material in this research was rattan species (Figure 1). The rattan sample was collected from the research sites for identifying each species. Each species was taken three sample specimens each. Part of the specimen was collected from the stem, leaf, tendril or flagellum, flower, and fruit (if any). This research is a basic study that collected data in the field. Therefore, this study used descriptive methods. The populations in this study were rattan species grow naturally in the Parigi Moutong and Sigi, Central Sulawesi Production Forests. Rattan specimens were stored in the Biology Education Laboratory, Faculty of Teacher Training and Education, Tadulako University, and Herbarium Celebensis of Tadulako University.

Central Sulawesi Province is located at the position of $2022^{\prime} \mathrm{LU}$ and 3048 'LS, 119022' and $124022^{\prime} \mathrm{BT}$, crossed by the Khatuliswiwa Line. The area where rattan is growing, including the research location, is highlands and classified as tropical rain forest. Altitude generally reaches 500 masl, although the highest location is the peak of Mount Nokilalaki which can reach 2610 masl. Nearly $48 \%$ of Central Sulawesi is mountains.

The equator that crosses the peninsula of the northern part of Central Sulawesi makes the climate of this area tropical. However, it is different from Java, Bali and parts of Sumatra. The rainy season in Central Sulawesi is between April and September, while the dry season is between October and March. The average rainfall ranges from 800 to 3,000 millimeters per year which is the lowest rainfall in Indonesia. The temperature ranges from 25 to 34 Celsius for plains and beaches with humidity levels between 71 to $76 \%$. In mountain areas the temperature can reach 16 to Celsius.

In general, these environmental conditions allow rattan to grow and develop well in the Central Sulawesi region, and can even grow at high altitude of 1 - 2500 masl. The growth and development of rattan is strongly influenced by various factors, including environmental factors, such as climate, rainfall and humidity

Since the Central Sulawesi Production Forest area is quite extensive, determine the location of the study in the two regions as a representation of production forests in Parigi Moutong and Sigi, Central Sulawesi, namely Production Forests in Siniu Village, Siniu Sub-District, Parigi Moutong Regency (0'33'04.5'S 120'01'41.1'E) and Production Forests in Namo Village, Kulawi Sub-District, Sigi Regency (1'23'14.9'S 119'59'12.8'E). Both locations have sufficient rattan potential to represent production forests in Parigi Moutong and Sigi, Central Sulawesi. At each location, samples were collected using a "purposive sampling" technique.

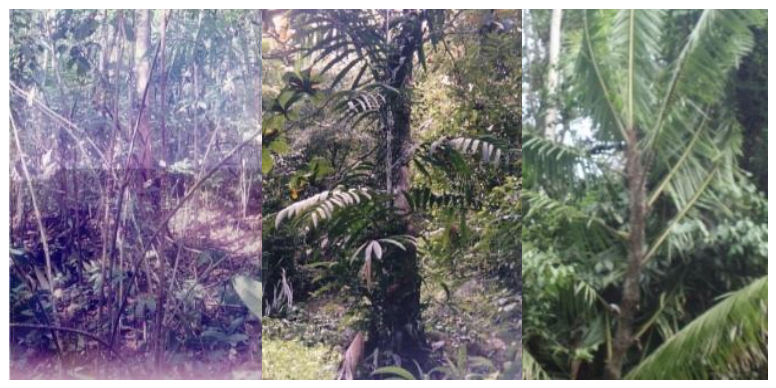

Figure 1. Rattan species which are the object of observation

Each location was divided into four regions, namely, north, east, south, and west. In each location, each region was randomly assigned. Thus, there were eight areas in total. In the selected sampling area, vegetation sampling was carried out using the systematic strip sampling method with the sample unit in the form of a path. The samples were $20 \mathrm{~m}$ wide and $100 \mathrm{~m}$ long.

The parameters observed were the development potential of each species, distribution patterns, and morphological characteristics. Identification and determination of the name of each rattan were carried out at Herbarium Celebensis, Tadulako University. Each species of the herbarium is made, and specimens are stored at Herbarium Celebensis. Data processing regarding the potential species was carried out according to the modified analytical procedures proposed.

After retrieving the data, the values of density, relative density, dominance, relative dominance, frequency, relative frequency, and important value of rattan species were determined by the following calculation below [20, 21]:

$$
\mathrm{Dy}=\frac{\mathrm{Nj}}{A}
$$

where, Dy is density, $\mathrm{Nj}$ is number of species, $\mathrm{A}$ is total sampled area.

$$
\mathrm{RDy}=\frac{\mathrm{Ds}}{\sum D s} \times 100 \%
$$

where, RDy is relative density, Ds is density of a species, $\Sigma$ Ds is total density of all species.

$$
\text { Do }=\frac{\text { BA }}{A}
$$

where, Do is dominance, BA is total basal area of species, A is total sampled area. 


$$
\mathrm{RDo}=\frac{D_{o s}}{\sum D_{o s}} \times 100 \%
$$

where, RDo is relative dominance, $D_{o s}$ is dominance of a species, $\Sigma D_{o s}$ is total dominance of all species.

$$
\mathrm{F}=\frac{\mathrm{So}}{A}
$$

where, $\mathrm{F}$ is frequency, So is Area of plots in which a species occurs, A is total sampled area.

$$
\mathrm{FR}=\frac{F_{o s}}{\sum F_{o s}} \times 100 \%
$$

where, FR is relative frequency, $F_{o S}$ is frequency of a species, $\Sigma F_{o S}$ is total frequency of all species. $V_{i}$ is important value. $V_{i}=\mathrm{RDy}+\mathrm{RDo}+\mathrm{FR}$.

\section{RESULTS \& DISCUSSIONS}

Based on the identification results, 17 species of rattan were collected from the study location, and the name of each type was determined (Table 1). The morphological properties of each species are presented in Table 2 and Table 3. The important values of each species are presented in Table 4, and the distribution patterns are presented in Table 5 .

Table 1. Types of rattan in the Central Sulawesi production forest

\begin{tabular}{cc}
\hline No. & Species Name \\
\hline 1 & Calamus didymocarpus (Mart) Becc. \\
2 & Calamus inops Becc. \\
3 & Calamus insignis Griff. \\
4 & Calamus koordersianus Becc. \\
5 & Calamus lejocaulis Becc. \\
6 & Calamus minahassae Warb. (dato) \\
7 & Calamus ornatus var. celebicus Becc. \\
8 & Calamus ornatus var. celebicus Becc. (lambang) \\
9 & Calamus orthostachyus Becc. \\
10 & Calamus symphisipus Becc. \\
11 & Calamus zollingerii Becc \\
12 & Calamus sp. (sambuta) \\
13 & Calamus sp. (uweepe) \\
14 & Calamus sp. (tohiti) \\
15 & Daemonorops lamprolepsis Becc. \\
16 & Daemonorops robusta Blume. \\
17 & Daemonorops sp. \\
\hline
\end{tabular}

Based on the results of the observations, it was determined that the rattan grew as a liana (grow climbing and sticking to the host tree) in both clumped and solitary growth habits. In the forest, the rattan grows naturally, and the stems appear prickly because the young stems remain covered by thorny midribs. Thus, only the part of the stem that is old or mature in the lower, unbroken portion of the plant will appear to be a real rattan stem without thorns.

In cross-section, the stem was round with a flat or grooved texture. The depth of grooves varied by type. The stem was segmented with segments of varying lengths. The diameter varied from small $(0.5-1.0 \mathrm{~cm})$, medium $(1.1-2.0 \mathrm{~cm})$ and large $>2 \mathrm{~cm}$ ), and plants reached up to $200 \mathrm{~m}$ in length. The stem surface had several colors, such as green, yellow, blue, or gray. The surface appearance was dull, slightly dull, or shiny.

Rattan leaves generally consist of three parts: the midrib, stem, and leaflets. The midrib grows into a petiole that connects the leaves. The length and size of the midribs vary by species. The frond arrangement is overlapping such that one midrib not only directly wraps the rattan stem but can also wrap two to four younger leaf midribs. Generally, the spread pattern of thorny rattan midribs decreases from the midrib base to the tip of the midrib. The density, color, and size of thorns vary by species. In the midrib that is wrapped by the outer midrib, the thorns do not develop well, so they remain soft, lie down, and are attached to the midrib surface.

The length of the stem is shorter than that of the stem. Spiny leaves have fewer or no thorns on the midrib. The leaf stalks are very short, even seeming to be nonexistent, so the leaves areas if they are directly attached to the spiraling shoots, as seen in Calamus insignis and $C$. ornatus var. celebicus (Lambang). Except for in the Korthalsia celebica small stalk, in which the leaves appear clearer but are still very short, this type was not found at the location of this study. Leaves are composed of pairs of leaflets whose numbers vary by species.

The leaves are positioned to face each other, and one is turned. The leaves are ribbon-shaped with sizes varying by species, except for $K$. celebica the leaves of the juveniles are lanceolate, but this species was not found in this study.

At the bottom of the rack, there are sometimes small numbers of thorns called indumentum. The indumentum is found mainly on the lower surface and edges of leaflets. Climbing tools occur in the form of flagella and tendril. Flagella are a modified and sterile male flower, while tendril a smaller extension of the spiraling shoot. Both types of climbing tools are spiked hooks facing downward. Of the 17 species of rattan studied, 14 species had tendril, and only four species had flagella. Tendril and flagella play an important role as the main aid for climbing because of their ability to float in the air so that the rattan tip can easily attach to the stands of other plants around it. The species $C$. koordersianus, C. ornatus var. celebicus (Buku dalam), C. ornatus var. celebicus (Lambang), and C. symphysipus do not have tendril but do have flagella. This type of flagellum is the same as the tendril but occurs in a different location. The flagella face the end of the midrib or base of the stem. The spines on the tendril and flagella vary in color and size varying by species.

All species of rattan studied grow in mountain forest areas with an altitude of 130-1,200 m. above all, except for Daemonorops lamprolepis, which grows in swamps where the surrounding plant canopy is quite open. The condition of the soil where it grows is moist to wet. The results showed that in the Parigi Moutong and Sigi, Central Sulawesi Production forest area, which can be accessed from the Banggai district, 17 species of rattan were found in the two genera, namely, Calamus, 14 species, and Daemonorops, three species. Of the 17 species, nine species had a clumped growth habit, while the other nine species were solitary (i.e., single-trunked).

The number of types of rattan in the forest area was approximately $5.46 \%$. This number was lower than the total found in Central Sulawesi, which has as many as 36 species $[14,22]$. This is almost the same as the amount found in the PangiBinangga Nature Reserve as 15 species [14], the Bancea Tourism forest as 18 species [23], and the Tinombala protected forest as 20 species [24].

This low number of types is caused by the narrowing of the forest area due to community intervention in the clearing of plantation land and as a result of rattan picking efforts by rattan 
farmers without equal cultivation efforts. Rattan collection activities are high enough that some species of rattan may be extinct. Also, the low number of species is thought to be caused by the terrain of the study site, which is quite complex and has a fairly steep slope so that the sampling range is very limited.

The observations of the morphology and habitat of each type of rattan, as presented in Appendix 2, illustrate a brief description of the characteristics of the 18 species of rattan studied. The numbers listed in the table represent the average of the observed samples. The results of the observations about the nature and characteristics of rattan indicate differences with the results of previous studies, such as the species of rattan that grows in the Lore Lindu Protected Forest, the Pangi Binangga nature reserve forest, and the Tinombala protected forest. These differences are thought to be caused by environmental influences and/or the plasticity of the rattan plant itself. These differences are relatively small and are mainly shown in terms of size, but morphologically, there are no fundamental differences for the same rattan species. Thus, these differences do not constitute type variations $[14,18]$.
In this study, the species of rattan studied consisted of two growth habits: solitary and clustered. The species of rattan that are solitary grow alone (i.e., single-trunked). This fact is not different from the species of rattan that were found previously $[25,26]$. Clumping rattan is caused by underground branching commonly found in rattan. However, this form of branching on land is rarely found. Korthalsia celebica is one example of rattan that shows a branching model above the ground, and in this study, it was found in very limited numbers and distributions. The branching of rattan, both underground and aboveground, is dichotomous.

The leaves of the 17 species rattan studied were relatively uniform in shape, with their sizes differing depending on the type. All types of rattan studied had irregular pinnate leaves with ribbon-shaped juvenile leaves, except the leaves of $\mathrm{K}$. celebica, which were lanceolate [27], but such types were not found in this study. Rattan leaves generally have small, fine spines known as indumentum [28]. The amount, density, and distribution vary according to species. All rattan types grew on a slightly to a steeply sloping mountain with an altitude of 1301,200 m.dpl and a slope of 18 s.d. $72.4^{\circ}$.

Table 2. Rattan stem and leaf morphological observations and environmental conditions

\begin{tabular}{|c|c|c|c|c|c|}
\hline \multirow[b]{2}{*}{ Species Name } & \multicolumn{5}{|c|}{ Stem } \\
\hline & Length $(\mathbf{c m})$ & Diameter $(\mathbf{c m})$ & Color & $\begin{array}{l}\text { Surface } \\
\text { Texture }\end{array}$ & Appearance \\
\hline Calamus didymocarpus & 45.6 & 2.4 & Light yellow & Flat & Shiny \\
\hline Calamus inops & 32.2 & 1.4 & Light blue & Flat & Shiny \\
\hline Calamus insignis & 17.1 & 0.8 & Green & Flat & Shiny \\
\hline Calamus koordersianus & 52.8 & 2.3 & Gray & Grooved & Dull \\
\hline Calamus lejocaulis & 37.2 & 1.1 & Green & Flat & Shiny \\
\hline Calamus minahassae(dato) & 23.8 & 1.1 & Light yellow & Flat & Shiny \\
\hline Calamus ornatusvar. Celebicus (bukudalam) & 44.7 & 2.2 & Greenish blue & Flat & Shiny \\
\hline Calamus ornatus var. celebicus (lambang) & 42.4 & 1.4 & Green & Flat & Slightly dull \\
\hline Calamus orthostachyus & 17.2 & 1.2 & Light blue & Grooved & Dull \\
\hline Calamus symphisipus & 47.6 & 2.1 & Light blue & Flat & Shiny \\
\hline Calamus zollingerii & 46.6 & 2.5 & Gray & Flat & Shiny \\
\hline Calamus sp. (sambuta) & 25.9 & 1.6 & Yellowish green & Flat & Little Shiny \\
\hline Calamus sp. (uweepe) & 38.2 & 1.9 & Light yellow & Flat & Dull \\
\hline Calamus sp. (tohiti) & 18.8 & 1.3 & Light yellow & Flat & Shiny \\
\hline Daemonoropslamprolepsis & 19.8 & 1.9 & Yellowish white & Flat & Shiny \\
\hline Daemonoropsrobusta & 46.2 & 3.1 & Green & Flat & Dull \\
\hline Daemonoropssp & 60.4 & 2.7 & Light blue & Grooved & Dull \\
\hline
\end{tabular}

\begin{tabular}{|c|c|c|c|c|c|}
\hline Species Name & $\begin{array}{l}\text { Midrib length } \\
(\mathrm{cm})\end{array}$ & $\begin{array}{l}\text { Stalk length } \\
(\mathrm{cm})\end{array}$ & $\begin{array}{c}\text { Leaf } \\
\text { Length of strands } \\
(\mathrm{cm})\end{array}$ & $\begin{array}{l}\text { Width of strands } \\
(\mathbf{c m})\end{array}$ & $\begin{array}{l}\text { Pinnate } \\
\text { nature }\end{array}$ \\
\hline Calamus didymocarpus & 62.6 & 7.1 & 150.7 & 45.2 & Uniform \\
\hline Calamus inops & 71.6 & 12.4 & 218.4 & 75.8 & Uniform \\
\hline Calamus insignis & 44.8 & 14.6 & 48.2 & 38.8 & Clustered \\
\hline Calamus koordersianus & 86.8 & 68.9 & 172.6 & 110.4 & Uniform \\
\hline Calamus lejocaulis & 73.8 & 9.4 & 109.7 & 44.7 & Uniform \\
\hline Calamus minahassae(dato) & 48.8 & 20.6 & 188.4 & 108.6 & Uniform \\
\hline $\begin{array}{c}\text { Calamus ornatusvar. Celebicus } \\
\text { (bukudalam) }\end{array}$ & 72.5 & 50.8 & 172.4 & 92.2 & Uniform \\
\hline $\begin{array}{c}\text { Calamus ornatus var. celebicus } \\
\text { (lambang) }\end{array}$ & 86.8 & 51.2 & 210.5 & 112.4 & Uniform \\
\hline Calamus orthostachyus & 46.8 & 27.2 & 94.6 & 67.4 & Uniform \\
\hline Calamus symphisipus & 68.6 & 54.8 & 148.2 & 74.2 & Uniform \\
\hline Calamus zollingerii & 84.8 & 56.8 & 209.7 & 118.2 & Uniform \\
\hline Calamus sp. (sambuta) & 48.8 & 24.6 & 129.2 & 48.6 & Uniform \\
\hline Calamus sp. (uweepe) & 72.4 & 40.8 & 210.6 & 82.4 & Uniform \\
\hline Calamus sp. (tohiti) & 28.2 & 3.7 & 54.8 & 68.3 & Uniform \\
\hline Daemonoropslamprolepsis & 88.4 & 17.2 & 158.9 & 49.6 & Uniform \\
\hline Daemonoropsrobusta & 48.2 & 18.7 & 208.6 & 139.3 & Uniform + 1 \\
\hline Daemonoropssp & 80.8 & 52.9 & 258.4 & 100.4 & Uniform \\
\hline
\end{tabular}




\begin{tabular}{|c|c|c|c|c|c|c|c|c|}
\hline \multirow[t]{2}{*}{ Species Name } & \multicolumn{3}{|c|}{ Climbing structure } & \multicolumn{5}{|c|}{ Leaflets } \\
\hline & Type & $\begin{array}{l}\text { Length } \\
\text { (cm) }\end{array}$ & $\begin{array}{l}\text { Total } \\
\text { (PS) }\end{array}$ & Bottom & $\begin{array}{r}\text { ndumentum } \\
\text { Top }\end{array}$ & $\underset{\text { point }}{\operatorname{Tip}}$ & $\begin{array}{l}\text { Measur } \\
\text { Length }\end{array}$ & $\begin{array}{l}\text { ements } \\
\text { Width }\end{array}$ \\
\hline Calamus didymocarpus & Tendril & 156.2 & 68 & - & Slightly spread & Exist & 41.4 & 4.4 \\
\hline Calamus inops & Tendril & 156.2 & 49 & - & Slightly scattered & Exist & 42.6 & 2.8 \\
\hline Calamus insignis & Tendril & 36.4 & 7 & - & - & Exist & 19.7 & 3.5 \\
\hline Calamus koordersianus & Flagella & 188.0 & 63 & $\begin{array}{l}\text { Slightly spread on the } \\
\text { bone }\end{array}$ & $\begin{array}{l}\text { Slightly spread on the } \\
\text { side }\end{array}$ & Exist & 46.8 & 2.3 \\
\hline Calamus lejocaulis & Tendril & 118.6 & 15 & - & Somewhat present & Exist & 33.2 & 2.8 \\
\hline Calamus minahassae(dato) & Tendril & 183.7 & 23 & - & Slightly scattered & Exist & 56.8 & 5.9 \\
\hline $\begin{array}{c}\text { Calamus ornatusvar. celebicus } \\
\text { (bukudalam) }\end{array}$ & Flagella & 326.7 & 22 & - & Many scattered & Exist & 40.8 & 5.6 \\
\hline $\begin{array}{c}\text { Calamus ornatus var. celebicus } \\
\text { (lambang) }\end{array}$ & Flagella & 254.7 & 16 & - & - & Exist & 69.4 & 5.6 \\
\hline Calamus orthostachyus & Tendril & 40 & 11 & Many scattered & Slightly scattered & Exist & 29.6 & 2.8 \\
\hline Calamus symphisipus & Flagella & 238.9 & 24 & - & - & Exist & 40.4 & 5.8 \\
\hline Calamus zollingerii & Tendril & 182.8 & 82 & - & Spread on its side & Exist & 62.5 & 2.8 \\
\hline Calamus sp. (sambuta) & Tendril & 88.7 & 70 & Many scattered & Slightly scattered & - & 43.7 & 0.9 \\
\hline Calamus sp. (uweepe) & Tendril & 128.6 & 72 & Some on the bone & $\begin{array}{l}\text { Some on the edge of the } \\
\text { bone }\end{array}$ & - & 36.7 & 1.8 \\
\hline Calamus sp. (tohiti) & Tendril & 60.4 & 15 & - & - & Exist & 40.9 & 3.2 \\
\hline Daemonoropslamprolepsis & Tendril & 139.5 & 66 & Some on the bone & Some on the bone & - & 23.6 & 1.8 \\
\hline Daemonoropsrobusta & Tendril & 220.4 & 34 & - & Some on the bone leaf & Exist & 138.8 & 3.6 \\
\hline Daemonoropssp & Tendril & 112.7 & 52 & - & - & Exist & 54.8 & 2.7 \\
\hline
\end{tabular}

Table 3. Rattan thorn and growth nature conditions

\begin{tabular}{|c|c|c|c|c|c|c|c|}
\hline \multirow{3}{*}{ No } & \multirow{3}{*}{ Species Name } & \multicolumn{4}{|c|}{ Thorn } & \multicolumn{2}{|c|}{ Growth nature } \\
\hline & & \multicolumn{2}{|c|}{ Midrib } & \multicolumn{2}{|c|}{ Climbing structure } & \multirow{2}{*}{$\begin{array}{c}\text { Clustered/ } \\
\text { solitary }\end{array}$} & \multirow{2}{*}{$\begin{array}{l}\text { Surrounding } \\
\text { canopy }\end{array}$} \\
\hline & & Color & Arrangement & Color & Arrangement & & \\
\hline 1 & Calamus didymocarpus & Light yellow & Slightly spread & Tawny & Clustered & Clustered & Closed \\
\hline 2 & Calamus inops & Gray & Many scattered & Yellow & Clustered & Solitary & Closed \\
\hline 3 & Calamus insignis & - & - & Black & Clustered & Solitary & Closed \\
\hline 4 & Calamus koordersianus & Blackish brown & Slightly scattered & Brown & Clustered & Solitary & Closed \\
\hline 5 & Calamus lejocaulis & Light yellow & Slightly scattered & Yellow & Clustered & Clustered & Closed \\
\hline 6 & Calamus minahassae(dato) & Brown & Many scattered & $\begin{array}{l}\text { Blackish } \\
\text { brown }\end{array}$ & Clustered & Solitary & Closed \\
\hline 7 & $\begin{array}{c}\text { Calamus ornatusvar. celebicus } \\
\text { (buku dalam) }\end{array}$ & Light yellow & Very little & Yellow & Clustered & Clustered & Closed \\
\hline 8 & $\begin{array}{c}\text { Calamus ornatus var. celebicus } \\
\text { (lambang) }\end{array}$ & - & - & Yellow & Clustered & Clustered & Closed \\
\hline 9 & Calamus orthostachyus & Light brown & Slightly scattered & Black & Clustered & Solitary & Closed \\
\hline 10 & Calamus symphisipus & Light yellow & $\begin{array}{l}\text { Slightly spread on } \\
\text { the side }\end{array}$ & Yellow & Clustered & Solitary & Closed \\
\hline 11 & Calamus zollingerii & Light yellow & Many & Yellow & Clustered & Clustered & Closed \\
\hline 12 & Calamus sp. (sambuta) & Brown & Many scattered & Yellow & Clustered & Solitary & Closed \\
\hline 13 & Calamus sp. (uweepe) & Blackish brown & Many & Yellow & Clustered & Clustered & Closed \\
\hline 14 & Calamus sp. (tohiti) & Greenish yellow & $\begin{array}{l}\text { Many, organized as a } \\
\text { spiral }\end{array}$ & $\begin{array}{l}\text { Blackish } \\
\text { brown }\end{array}$ & Clustered & Solitary & Closed \\
\hline 15 & Daemonoropslamprolepsis & Light brown & Many & Brown & Clustered & Clustered & Open \\
\hline 16 & Daemonoropsrobusta & Light yellow & Scattered & Tawny & Clustered & Clustered & Closed \\
\hline 17 & Daemonoropssp & Blackish brown & Many & Brown & Clustered & Clustered & Closed \\
\hline
\end{tabular}

Table 4. Importance values of rattan species in Central Sulawesi production forest area

\begin{tabular}{|c|c|c|c|c|c|c|c|}
\hline \multirow{2}{*}{ No } & \multirow{2}{*}{ Species Name } & \multicolumn{4}{|c|}{ Importance Value in Each Location } & \multirow{2}{*}{ Total } & \multirow{2}{*}{ Average } \\
\hline & & North & East & South & West & & \\
\hline 1 & C. didymocarpus (Mart) Becc. & 23.29 & 24.39 & 22.08 & 22.21 & 91.97 & 22.99 \\
\hline 2 & C. inops Becc. & 22.64 & 21.11 & 22.46 & 22.80 & 89.01 & 22.25 \\
\hline 3 & C. insignis Griff & 13.34 & 14.37 & 12.93 & 13.38 & 54.02 & 13.51 \\
\hline 4 & C. oodersianus Becc. & 24.32 & 23.17 & 22.54 & 24.21 & 94.24 & 23.56 \\
\hline 5 & C. lejocaulis Becc. & 16.91 & 16.38 & 15.18 & 14.82 & 63.29 & 15.82 \\
\hline 6 & C. minahassae Warb. (ronti) & 7.77 & 6.51 & 9.05 & 7.44 & 30.77 & 7.69 \\
\hline 7 & C. minahassae Warb. (dato) & 5.13 & 5.95 & 5.59 & 7.52 & 24.19 & 6.05 \\
\hline 8 & C. ornatus var. celebicus Becc. & 25.60 & 24.09 & 23.79 & 24.98 & 98.46 & 24.62 \\
\hline 9 & C. ornatus var. celebicus Becc. (lambang) & 22.92 & 25.72 & 23.66 & 21.67 & 93.97 & 23.49 \\
\hline 10 & C. orthostachyus Becc. & 6.82 & 7.78 & 8.25 & 9.49 & 32.34 & 8.09 \\
\hline 11 & C. symphisipus Becc. & 5.86 & 6.99 & 8.66 & 7.76 & 29.27 & 7.32 \\
\hline 12 & C. zollingerii Becc. & 39.24 & 37.62 & 35.04 & 34.56 & 146.46 & 36.62 \\
\hline 13 & Calamus sp. (sambuta) & 17.67 & 19.08 & 18.64 & 16.60 & 71.99 & 18.00 \\
\hline
\end{tabular}




\begin{tabular}{lccccccc}
\hline 14 & Calamus sp. (uweepe) & 10.24 & 8.30 & 12.53 & 12.00 & 43.07 & 10.77 \\
15 & D. lamprolepsis Becc. & 5.29 & 5.70 & 10.39 & 8.56 & 29.94 & 7.49 \\
16 & D. robusta Blume. & 16.37 & 15.24 & 15.73 & 14.19 & 61.53 & 15.38 \\
17 & Daemonorops sp. & 11.77 & 10.87 & 12.47 & 15.09 & 50.2 & 12.55 \\
\hline \multicolumn{1}{c}{ Average } \\
\hline
\end{tabular}

Table 5. Growth patterns and natural growth types of Central Sulawesi production forest

\begin{tabular}{|c|c|c|c|c|c|c|}
\hline \multirow{2}{*}{ No } & \multirow{2}{*}{ Species Name } & \multicolumn{3}{|c|}{ Distribution Pattern } & \multirow{2}{*}{$\%$} & \multirow{2}{*}{ Nature of growth } \\
\hline & & Evenly & Unevenly & Groups & & \\
\hline 1 & C. didymocarpus (Mart) Becc. & 90 & 7 & 3 & 100 & Clustered \\
\hline 2 & C. inops Becc. & 98 & 1 & 1 & 100 & Solitary \\
\hline 3 & C. insignis Griff & 95 & 3 & 2 & 100 & Solitary \\
\hline 4 & C. koordersianus Becc. & 94 & 4 & 2 & 100 & Solitary \\
\hline 5 & C. lejocaulis Becc. & 96 & 3 & 1 & 100 & Clustered \\
\hline 6 & C. minahassae Warb. (ronti) & 11 & 71 & 18 & 100 & Solitary \\
\hline 7 & C. minahassae Warb. (dato) & 8 & 79 & 13 & 100 & Solitary \\
\hline 8 & C. ornatus var. celebicus & 89 & 9 & 2 & 100 & Clustered \\
\hline 9 & C. ornatus var. celebicus (lambang) & 93 & 5 & 2 & 100 & Clustered \\
\hline 10 & C. orthostachyus Becc. & 89 & 6 & 5 & 100 & Solitary \\
\hline 11 & C. symphisipus Becc. & 8 & 12 & 80 & 100 & Solitary \\
\hline 12 & C. zollingerii Becc. & 98 & 1 & 1 & 100 & Clustered \\
\hline 13 & Calamus sp. (sambuta) & 77 & 17 & 6 & 100 & Solitary \\
\hline 14 & Calamus sp. (uweepe) & 5 & 19 & 76 & 100 & Clustered \\
\hline 15 & D. lamprolepsis Becc. & 12 & 78 & 10 & 100 & Clustered \\
\hline 16 & D. robusta Blume. & 24 & 65 & 11 & 100 & Clustered \\
\hline 17 & Daemonorops sp. & 3 & 81 & 16 & 100 & Clustered \\
\hline
\end{tabular}

Based on observations, it is known that rattan is found together (both same-sex and other species) in the production area of Central Sulawesi. This is possible because of the isolation caused by the difficulty of dispersing because seeds are difficult to grow in new areas. The pattern of the distribution of rattan species includes three forms, in which plants are spread evenly, unevenly, and in groups, with the groups found in all parts of the forest from swamps to mountain peaks. The most common pattern of spread is an even distribution. Such a pattern is relatively similar to the rattan distribution pattern found in other regions of Central Sulawesi [23].

The potential for stands of each species varies widely. This might be due to habitat factors, patterns of distribution, and forms of life. The calculation results show that the importance values of each species vary from 6.05 to 36.62, with an average of 16.67. These variations indicate that each species has a varying abundance. High levels of abundance illustrate the high level of potential stands. Thus, it can be expected that the types of rattan that have high importance are the species that have a high level of potential stands, whereas, for the species that have low importance, the level of potential of the stand is low. The potential of stands of rattan species found in the study region is generally higher than the potential of stands in other regions in Parigi Moutong and Sigi, Central Sulawesi.

Based on the calculation of the importance values of each species, Calamus zollingerii is the species of rattan with the highest stand potential of all of the species of rattan in the Parigi Moutong and Sigi, Central Sulawesi production forest area. This situation is the same as those in other conservation forests in Central Sulawesi. This fact also shows that this rattan species has a high economic value compared to other types of rattan. This statement is based on the results of interviews with rattan farmer groups in the two research locations. In the rattan trade, two groups are distinguished, namely commercial types of rattan and non-commercial types of rattan. Commercial types of rattan are the types of rattan that can be sold in the rattan trade, and having high economic value. Noncommercial types of rattan are the types that are not traded.
(Anwar; Group Leader Rattan Farmer in Desa Namo and Ramli, Group Leader Rattan Farmer Desa Siniu). Also, this type of rattan has the best quality of all other species of rattan. If viewed from the potential value of each rattan species in the Parigi Moutong and Sigi, Central Sulawesi production forest area, this area can be said to have a fairly high potential. However, compared with the potential types of timber plants, the rattan potential in the forest area is relatively low because it is still below $40 \%$.

Based on the results and discussion, it can be explained that the number of species of rattan found is 17 , or approximately $5.46 \%$ of the total 513 species of rattan in Indonesia. This amount is relatively high compared to the amount found in other regions. The rattan is divided into two genera, with 15 species belonging to Calamus and three types belonging to Daemonorops. The average potential in the production forest of Central Sulawesi for both species and stands is higher when compared to the other regions in Parigi Moutong and Sigi, Central Sulawesi. Thus, the rattan species have a high potential for the collection of germplasms and regional economic value.

Nine rattan species have the above-mentioned potential value, on average, and the type of rattan with the highest value is Calamus zollingerii. These nine species of rattan are widespread and evenly distributed in all observed locations. The rattan distribution in the Parigi Moutong and Sigi, Central Sulawesi production forest area, varies according to species and habitat. The spread pattern is mainly in the form of an even distribution. The rattan species found in production forest Central Sulawesi's show small differences in size but morphologically still have the same pattern and structure as the species of rattan found in other regions. Thus, the difference is not a species variation but is a characteristic of the plasticity of the rattan itself.

\section{CONCLUSION}

Our observations found the number of species of rattan found is relatively high compared to the amount found in other 
regions. The rattan is divided into two genera, Calamus and Daemonorops. The average potential in the production forest of Central Sulawesi for both species and stands is higher than the other regions in Sulawesi. The distribution of rattan in the production forest of the Central Sulawesi area is varied according to species and habitat.

\section{ACKNOWLEDGMENT}

Thank you to the Dean of Faculty of Teacher Training and Education, Tadulako University, for funding the implementation of this research so that this research could be completed as expected.

\section{REFERENCES}

[1] Chan, C.S.Y., Cheng, J., Loh, J.Y.Q., Tan, E., Loo, A.H.B., Tang, J.H. (2012). Observations of ants and aphids in the rattan species Korthalsia echinometra becc. and Korthalsia rostrata blume. Raffles Bull Zool, 25: 133-139.

[2] Dransfield, J., Uhl, N.W., Asmussen, C.B., Baker, W.J., Harley, M.M., Lewis, C.E. (2008). Genera Palmarum The Evolution and Classification of the Palms. Royal Botanic Gardens, Kew.

[3] Widayati, A., Jones, S., Carlisle, B. (2010). Accessibility factors and conservation forest designation affecting rattan cane harvesting in Lambusango Forest, Buton, Indonesia. Human Ecology, 38(6): 731-746. https://doi.org/10.1007/s10745-010-9358-7

[4] Krisdianto, K., Jasni, J., Tutiana, T. (2018). Anatomical properties of nine indigenous rattan species of Jambi, Indonesia. Indonesian Journal of Forestry Research, 5(2): 147-161. https://doi.org/10.20886/ijfr.2018.5.2.147-161

[5] Astana, S., Nasendi, B. (1998). Wild Rattan in Sulawesi: A Case Study of the Production-to-Consumption Systems. INBAR.

[6] Siebert, S.F. (2005). The abundance and distribution of rattan over an elevation gradient in Sulawesi, Indonesia Forest Ecology and Management, 210(1-3): 143-158. https://doi.org/10.1016/j.foreco.2005.02.015

[7] Belcher, B., Imang, N., Achdiawan, R. (2004). Rattan, rubber, or oil palm: cultural and financial considerations for farmers in Kalimantan. Economic Botany, 58(1): S77-S87. https://doi.org/10.1663/00130001(2004)58[77:RROOPC]2.0.CO;2

[8] Jamaludin, M., Firdaus, B.A.T., Subkiman, A. (2018). The influence of Scandinavian furniture design in the development of modern rattan furniture in Indonesia. Journal of Arts and Humanities, 7(3): 19-26. https://doi.org/10.18533/journal.v7i3.1350

[9] Warsito, B. (2019). Rattan as a craft material of community on the north coast of java (Rattan Craft Study in Teluk Wetan Jepara). E3S Web of Conferences, 125: 09018. https://doi.org/10.1051/e3sconf/201912509018

[10] Widayati, A., Carlisle, B. (2012). Impacts of rattan cane harvesting on vegetation structure and tree diversity of Conservation Forest in Buton, Indonesia. Forest Ecology and Management, 266: 206-215 https://doi.org/10.1016/j.foreco.2011.11.018

[11] Myers, R. (2015). What the Indonesian rattan export ban means for domestic and international markets, forests, and the livelihoods of rattan collectors. Forest Policy and Economics, 50 : 210-219. https://doi.org/10.1016/j.forpol.2014.07.009

[12] Komarudin, H., Siagian, Y.L. (2007). Linking collective action to non-timber forest product market for improved local livelihoods: Challenges and Opportunities (No. 577-2016-39146). https://doi.org/10.22004/AG.ECON.44346

[13] Abdurachman, A., Jasni, J., Pari, R., Satiti, E.R. (2017). Penggolongan 23 jenis rotan indonesia berdasarkan kerapatan dan kuat tarik sejajar serat. Jurnal Penelitian Hasil Hutan, 35(1): 43-52. https://doi.org/10.20886/jphh.2017.35.1.43-52

[14] Tellu, A.T. (2006). Cladistics of some rattans (Calamus spp.) from Central Sulawesi based on physical and mechanical characteristic of stems. Biodiversitas Journal of Biological Diversity, 7(3): 225-229. https://doi.org/10.13057/biodiv/d070306

[15] Henderson, A., Pitopang, R. (2018). The rattans (Arecaceae) of Wallacea. Biodiversitas Journal of Biological Diversity, 19(1): 18-21. https://doi.org/10.13057/biodiv/d190103

[16] Henderson, A., Iqbal, M., Rusydi, M., Pitopang, R. (2018). A new species of Calamus (Calaminae, Calamoideae, Arecaceae) from Sulawesi, Indonesia. Phytotaxa, 345(3): 298-300. https://doi.org/10.11646/phytotaxa.345.3.7

[17] Sanusi, D. (2012). Rotan kekayaan belantara Indonesia, Cet. 1. Surabaya: Brilian Internasional. https://mday.info/result/detail/detail.php?idN=3083\&titl e=Rotan\%20kekayaan\%20belantara\%20Indonesia.

[18] Kunut, A.A., Sudhartono, A., Toknok, B. (2014). Keanekaragaman jenis rotan (Calamus spp.) di kawasan hutan lindung wilayah Kecamatan Dampelas Sojol, Kabupaten Donggala. Warta Rimba, 2(2): 102-108.

[19] Culmsee, H., Pitopang, R., Mangopo, H., Sabir, S. (2011). Tree diversity and phytogeographical patterns of tropical high mountain rain forests in Central Sulawesi, Indonesia. Biodiversity and Conservation, 20(5): 1103-1123. https://doi.org/10.1007/s10531-011-0019-y

[20] Solikin, S. (2013). Diversity of bamboos around springs in Malang East Java. Berkala Penelitian Hayati, 19(1): $38-42$.

[21] Murdjoko, A., Marsono, D., Sadono, R., Hadisusanto, S. (2016). Plant species composition and their conspecific association in natural tropical rainforest, South Papua. Biosaintifika: Journal of Biology \& Biology Education, 8(1): $33-46$ https://doi.org/10.15294/biosaintifika.v8i1.5217

[22] Mogea, J. (1990). Survey Botani Rotan di Sulawesi Tenggara dan Sulawesi Selatan, Herbarium Bogoriense Balitbang Botani. Bogor: Puslitbang Biologi LIPI. http://www.biologi.lipi.go.id/.

[23] Tellu, A., Laenggeng, A. (1998). Potensi dan Pola Penyebaran Jenis - Jenis Rotan di Hutan Wisata Bancea Poso. Palu: Lembaga Penelitian University Tadulako. http://lppm.untad.ac.id/.

[24] Tellu, A. (1999). Potensi dan Pola Penyebaran Jenis Jenis Rotan di Hutan Lindung Tinombala Kabuapaten Donggala. Palu: Lembaga Penelitian University Tadulako. http://lppm.untad.ac.id/.

[25] Stiegel, S., Kessler, M., Getto, D., Thonhofer, J., Siebert, S.F. (2011). Elevational patterns of species richness and density of rattan palms (Arecaceae: Calamoideae) in 
Central Sulawesi, Indonesia. Biodiversity and Conservation, 20(9): 1987-2005 https://doi.org/10.1007/s10531-011-0070-8

[26] Rustiami, H., Mogea, J.P., Tjitrosoedirjo, S.S. (2011). Revision of the rattan genus Daemonorops (Palmae: Calamoideae) in Sulawesi using a phenetic analysis approach. The Gardens' Bulletin Singapore, 63(1): 17-30.

[27] Saroinsong, F.B. (2020). Supporting plant diversity and conservation through landscape planning: A case study in an agro-tourism landscape in Tampusu, North Sulawesi, Indonesia. Biodiversitas Journal of Biological Diversity, 21(4):

1518-1526. https://doi.org/10.13057/biodiv/d210432

[28] Sunderland, T.C. (2003). Two new species of rattan (Palmae: Calamoideae) from the forests of West and Central Africa. Kew Bulletin, 58(4): 987-990. 